\title{
Effects of dietary protein sources on the progression of renal failure without dialysis in rats
}

\author{
Nadia Saleh Al-Amoudi \\ Nutrition and Food Department. King Abdulaziz University, P.O. Box 3108 Jeddah 23435, Saudi Arabia \\ Email address: \\ alamudinadia@gmail.com
}

\section{To cite this article:}

Nadia Saleh Al-Amoudi. Effects of Dietary Protein Sources on the Progression of Renal Failure without Dialysis in Rats. Journal of Food and Nutrition Sciences. Vol. 1, No. 3, 2013, pp. 23-32. doi: 10.11648/j.jfns.20130103.11

\begin{abstract}
The quality and quantity of protein are essential factors that determine nutritional significance of a protein. The aim of this study was to compare the effects of several animal and plant proteins on the progression of renal failure in rats. Ninety male rats were allocated into nine groups and were fed with a basal diet containing different protein sources for 12 weeks. Two groups comprised of a negative control group and a positive control group (with induced renal failure) fed on the basal diet. Rats in the remaining seven groups were fed using different diets containing $10 \%$ protein derived from fish, meat, chicken, egg, soybean, lentil, and white bean. Biological, biochemical and histological studies were done at the end of the study. Protein content was highest for the chicken extract (87.36\%), followed by meat $(85.67 \%)$, egg $(78.85 \%)$, and fish $(78.55 \%)$. Body weight gain increased as food intake decreased in all groups other than the positive control group, and the food efficiency ratio paralleled food intake. Rats fed the fish protein diet had lower blood urea nitrogen $(28.0 \mathrm{mg} / \mathrm{dL})$, uric acid $(3.5 \mathrm{mg} / \mathrm{dL})$ levels compared with the other groups. There were no significant differences in creatinine levels between rats fed the animal protein (fish and meat) or the plant protein (soy and white bean) diets. Histological studies revealed no abnormal renal features in rats fed the fish or soybean protein diets. Therefore, the results of the study suggest that a diet containing fish protein may delay the progression of chronic renal failure relative to other protein diets.
\end{abstract}

Keywords: Animal Protein, Plant Protein, Rats, Renal Failure without Dialysis, Renal Function

\section{Introduction}

Patients with renal failure often experience malnutrition. For instance, a study done on the impact of malnutrition on renal failure indicates that about $40 \%$ of patients with renal failure experience malnutrition [1]. Although malnutrition has a multi-factorial impact on renal failure, insufficient intake of protein significantly contributes to the occurrence of renal failure. Generally, nutritionists recommend that (CKD) should take a low-protein diet because it is beneficial; however, the source of protein is another factor that determines the progression of renal failure. While many clinicians assume that a vegan diet is better for patients with CKD, the perceived benefits of this diet may not be true because the nature of protein determines its impact on renal failure. In particular, patients consuming a vegan diet may not consume beneficial secondary nutrients that are primarily present in animal products or may consume phytates and aluminum that are present in vegetarian sources, which are harmful to patients with CKD [2]. In this view, it is advisable that patients with
CKD should consume sufficient quantities of protein that are free from harmful substances.

Patients with CKD normally undergo dialysis. Although patients may try to avoid dialysis for many years, it is important that their low-protein diet should include sufficient protein to prevent cachexia while protecting the kidneys. To manage renal failure effectively, patients with CKD should take appropriate diet has minimal nitrogenous wastes because imbalances in nitrogenous metabolites enhances morbidity and mortality of patients with CKD [3]. A prospective study of patients with non-diabetic nephropathy and moderate-to-severe renal insufficiency who consumed a vegan diet $(0.7 \mathrm{~g}$ protein $/ \mathrm{kg} /$ day $)$ or an animal protein $(0.6 \mathrm{~g}$ protein $/ \mathrm{kg} /$ day $)$ for a period of 3 months showed that no significant differences in creatinine clearance exist [4]. In subsequent study of 22 patients with non-diabetic nephritis, who switched from a mixed animal/vegetable diet to either a conventional low-protein diet $(0.6 \mathrm{~g}$ protein $/ \mathrm{kg} /$ day $)$, or a vegan diet $(0.7 \mathrm{~g}$ protein $/ \mathrm{kg} /$ day); there was no marked changes in proteinuria after 4-6 months, but glomerular filtration rate 
(GFR) decreased similarly in both groups [5]. A further study conducted an eight-week randomized crossover study of eight individuals with diabetes, proteinuria, and moderate renal insufficiency reported that there was a decrease in the GFR following the consumption of an animal protein diet $(1 \mathrm{~g}$ protein $/ \mathrm{kg} /$ day $)$ and a soy protein diet (1 g protein/kg/day)[6]. Hence, the findings suggest that there is no advantage of a soy protein-based diet in the context of diabetic CKD.

Generally, the quality of protein can be classified into two groups; namely, low and high quality proteins. Low quality protein does not contain all essential amino acids required for use in protein synthesis whereas high quality protein contains most of the essential amino acids that is essential for the appropriate functioning of the human body system. Plant proteins are considered to be lower in quality than animal protein because they do not contain all essential amino acids .Nevertheless, protein from either source provide amino acids, which are important raw materials for the protein synthesis form component of metabolic regulators, and provide important energy [7]. Comparatively, animal proteins from food such as beef, fish, chicken, and dairy products a higher quality of protein than plant protein from food such as cereals, fruits and vegetables. Although plant and animal proteins have approximately the same types of amino acids, the proportion of the amino acids varies according to the protein sources. The nutritional quality of any protein relates to its amino acid composition, digestibility, and ability to supply the essential amino acids in the amounts required by the species consuming the protein [8]. Thus, sources of proteins determine the quality and digestibility of proteins.

Currently, some researchers recommend animal protein diets, while others advocate plant protein diets. Although several studies have been performed to compare animal protein and plant protein, very few studies have examined how proteins from different sources influence renal failure [9-13]. Therefore, it is important to compare the effects of different protein sources on renal function to determine their suitability to patients with renal failure. Consequently, the objective of the study was to compare the effects of several animal and plant protein diets on the biochemical and histopathological characteristics of rats with chemically induced chronic renal failure.

\section{Materials and Methods}

\subsection{Materials}

\subsubsection{Food Items}

Fish fillet, ground beef meat, chicken breast, lentil, and white bean were obtained from a local market (Jeddah, Saudi Arabia). Soybean and egg protein (pure albumin) were purchased from a local market in Cairo (Egypt). The researcher cleaned and milled all food items into a fine powder before using them at $10 \%$ in the diet, instead of the main source of protein in the basal diet (casein), according to the percent of protein of each food item.

\subsubsection{Gentamicin}

Obtained from Al-Nahdy pharmacy.

\subsubsection{Rats}

Purchased them from the Pharmacy College at King Saud University.

\subsection{Methods}

\subsubsection{Chemical Composition}

Crude protein, moisture, fat, fiber, and ash contents of each protein source were determined according to methods outlined by the Association of Official Analytical Chemists AOAC [14]. Carbohydrate content was determined using standard analytical procedures for the sake of accuracy.

\subsubsection{Biological Investigation}

Male albino rats Sprague Dawley strain (90 rats) weighing 130-150g were obtained from the Pharmacy College at King Saud University and were delivered to the King Fahd Medical Research Center in Jeddah. To enable rats acclimatize the new experimental environment, they were kept in well-aerated cages for a period of one week and fed on basal diet. The composition of the basal diet was $1 \%$ vitamin, $4 \%$ salt, $5 \%$ cellulose, $10 \%$ corn oil, $10 \%$ casein, and $70 \%$ cornstarch, as recommended in the protocol [15].

\subsubsection{Preparation of Renal Failure without Dialysis Rats}

Renal failure without dialysis was induced in normal healthy male albino rats via intra-peritoneal injection of gentamicin at a dose of $100 \mathrm{mg} / \mathrm{kg} \mathrm{b}$. wt. for7 days according to the evidence-based method [16].

\subsubsection{Experimental Design}

The study assigned 90 rats nine groups. The first group of rats was fed on basal diet and they acted as a negative control, while the rest 80 rats assigned to 8 groups acted as a positive control because they have renal failure without dialysis. The 90 rats were divided into nine groups $(n=10)$ according to the following scheme:

Group (A): non-renal failure control (negative control): one group

Group (B): Renal failure without dialysis main groups: 8 groups 


\begin{tabular}{llll}
\hline Groups & Treatment & Diet & Period \\
\hline 1 & Non renal failure control & Basal diet & 12 weeks \\
2 & Renal failure without dialysis main groups & Basal diet & 12 weeks \\
3 & Renal failure without dialysis main groups & Basal diet $+10 \%$ fish & 12 weeks \\
4 & Renal failure without dialysis main groups & Basal diet $+10 \%$ meat & 12 weeks \\
5 & Renal failure without dialysis main groups & Basal diet $+10 \%$ chicken & 12 weeks \\
6 & Renal failure without dialysis main groups & Basal diet $+10 \%$ egg & 12 weeks \\
7 & Renal failure without dialysis main groups & Basal diet $+10 \%$ soya bean & 12 weeks \\
8 & Renal failure without dialysis main groups & Basal diet $+10 \%$ lentil & 12 weeks \\
9 & Renal failure without dialysis main groups & Basal diet $+10 \%$ white bean & 12 weeks \\
\hline
\end{tabular}

The following table shows the composition of the experimental diets according to the percentage content of

proteins in different food sources relative to casein.

Table (1): Composition of the experimental diets

\begin{tabular}{lllllllll}
\hline Composition & Casein & Fish & Meat & Chicken & Egg & Soy & Lentil & $\begin{array}{l}\text { White } \\
\text { bean }\end{array}$ \\
\hline Protein & 100 & 127 & 117 & 114 & 127 & 195 & 397 & 422 \\
Corn oil & 100 & 87 & 95 & 96 & 99 & 90 & 95 & 96 \\
Corn starch & 353 & 339 & 341 & 343 & 327 & 268 & 61 & 35 \\
Sucrose & 350 & 350 & 350 & 350 & 350 & 350 & 350 & 350 \\
Cellulose & 50 & 50 & 50 & 50 & 50 & 50 & 50 & 50 \\
Salt mix & 35 & 35 & 35 & 35 & 35 & 35 & 35 & 35 \\
Vitamin & 10 & 10 & 10 & 10 & 10 & 10 & 10 & 10 \\
Choline bitartrate & 2 & 2 & 2 & 2 & 2 & 2 & 2 & 2 \\
\hline
\end{tabular}

During the experimental period of 12 weeks, the diet consumed was recorded every day, while body weight was recorded every week. Since different protein sources have different impacts on renal failure, rats were fasted overnight before they were slaughtered. During slaughter, blood samples were collected and stored in clean centrifuge tube where they were left for 15 minutes to clot. Thereafter, the clotted blood samples were centrifuged to obtain serum at $3000 \mathrm{rpm}$ for 15 minutes. Additionally, to examine the levels of various metabolites in the body, vital organs such as liver, spleen, lung, heart, and kidney were excised, weighed individually, and preserved in the fridge for pathological analysis.

\subsection{Biological Evaluation}

During the experimental period, the weights of all rats were determined weekly and recorded. At the end of the experimental period, body weight gained in percentage (BWG \%) and Food Efficiency Ratio (FER) was determined as a biological evaluation according to the following formulas [17].

\section{BWG $\%=\underline{\text { Final weight }- \text { Initial weight }} \times 100 \%$ Initial weight}

FER $=\underline{\text { Gain in body weight }(\mathrm{g})}$ Food intake (g)

\subsubsection{Analytical Methods}

Serum creatinine, serum uric acid, and blood urea nitrogen (BUN) levels, as markers of renal function, were determined using the biochemical methods described by three scientists respectively $[18,19,20]$.

Additionally, serum total protein and serum albumin levels were determined using the methods described by two scientists respectively [21, 22].

The level of serum globulin was determined using total protein and albumin, as the difference of the two metabolites. The levels of potassium $(\mathrm{K})$ and sodium $(\mathrm{Na})$ were calculated basing on the standard formula that is recommended [14].

\subsection{Histopathological Study}

To examine the impacts of protein diets on vital organs such as kidneys, lungs, liver, spleen, and heart, the organs were fixed using $10 \%$ formalin, which is buffered at neutral $\mathrm{PH}$, dehydrated in ethyl alcohol, then cleared in xylol and embedded in paraffin. Subsequently, 4-6 microns thickness sections prepared and stained with heamtoxylin and eosin for examining the liver using a light microscope at various magnifications [23].

\subsection{Statistical Analysis}

Data were compared between the 10 groups using analysis of variance (ANOVA) by following statistical 
analysis procedure in the book. In the comparative analysis, the means were compared at least significant difference level of 0.05 as described in statistical analysis [25].

\section{Results and Discussion}

Since proteins affect renal function, regulation of dietary proteins has proved to be essential in preservation of renal function. In addition to quantity, the quality of dietary protein is thought to affect renal function; however, the effects of protein on the renal function are still poorly understood. Thus, the study sought to establish the effect of protein quality on renal function by ascertaining differential impacts of plant and animal proteins on the progression of renal failure. In this view, the results of the present study revealed that out of all the animal and plant proteins tested, fish protein had the best effects of preventing the progression of renal failure among rats without dialysis.

\subsection{Chemical Composition of Protein Sources}

In the present study, dried fish, meat, chicken, egg, soybean, lentil and white bean were analyzed for their contents of moisture, fat, protein, fiber, ash and total carbohydrate, the results are given in table (2). The data show that moisture, fat, protein, fiber, ash and total carbohydrate content of fish is $4.36 \%, 10.27 \%, 78.55 \%$, $0.11 \%, 6.04 \%$, and $0.67 \%$ respectively, while that of meat is $1.75 \%, 4.48 \%, 85.67 \%, 0.09 \%, 2.79 \%$, and $5.22 \%$ respectively. Moreover, the moisture, fat, protein, fiber, ash and total carbohydrate content of chicken is $5.29 \%, 3.53 \%$, $87.36 \%, 0.19 \%, 3.11 \%$, and $0.52 \%$, while that of an egg is $7.88 \%, 0.25 \%, 78.85 \%, 0.26 \%, 5.23 \%$, and $7.53 \%$. For soya bean, it is $3.40 \%, 5.19 \%, 51.24 \%, 3.09 \%, 6.50 \%$, and $30.58 \%$, for lentil it is $8.09 \%, 1.32 \%, 25.18 \%, 1.48 \%$, $1.41 \%$, and $60.52 \%$, and ultimately for white bean is $5.49 \%$, $1.02 \%, 23.71 \%, 5.22 \%, 3.16 \%$ and $61.40 \%$ respectively. The data reveal that the protein content of animal sources is higher than plant sources. The highest content is present in chicken while the lowest content is present in white bean. These results are in agreement with the finding that recommends a target dietary protein content of $0.6-0.75$ $\mathrm{g} / \mathrm{kg} /$ day for patients with CKD [26].

Table (2): Chemical composition of fish, meat, chicken, egg, soybean, lentil, and white bean

\begin{tabular}{llllllll}
\hline $\begin{array}{l}\text { Foods } \\
\text { Components }\end{array}$ & $\begin{array}{l}\text { Fish } \\
\text { \% }\end{array}$ & $\begin{array}{l}\text { Meat } \\
\text { \% }\end{array}$ & $\begin{array}{l}\text { Chicken } \\
\text { \% }\end{array}$ & $\begin{array}{l}\text { Egg } \\
\text { \% }\end{array}$ & $\begin{array}{l}\text { Soybean } \\
\text { \% }\end{array}$ & $\begin{array}{l}\text { Lentil } \\
\text { \% }\end{array}$ & $\begin{array}{l}\text { White bean } \\
\text { \% }\end{array}$ \\
\hline Moisture & 4.36 & 1.75 & 5.29 & 7.88 & 3.40 & 8.09 & 1.32 \\
Fat & 10.27 & 4.48 & 3.53 & 0.25 & 5.19 & 1.02 \\
Protein & 78.55 & 85.67 & 87.36 & 78.85 & 51.24 & 25.18 \\
Fiber & 0.11 & 0.09 & 0.19 & 0.26 & 3.09 & 1.48 \\
Ash & 6.04 & 2.79 & 3.11 & 5.23 & 6.50 & 1.41 \\
T. carb. & 0.67 & 5.22 & 0.52 & 7.53 & 30.58 & 62.52 \\
\hline
\end{tabular}

\subsection{Biological Evaluation}

\subsubsection{Effect of Protein Sources on BWG, FI, and FER for Renal Failure without Dialysis Rats}

Data presented in table (3) show the effect of fish, meat, chicken, egg, soybean, lentil and white bean on body weight gain (BWG), food intake (FI), and feed efficiency ratio (FER) in rats with renal failure without dialysis.

Table (3): Effect of fish, meat, chicken, egg, soybean, lentil and white bean on body weight gain (BWG) food intake (FI), and feed efficiency ratio (FER) of renal failure without dialysis rats.

\begin{tabular}{llll}
\hline $\begin{array}{l}\text { Parameters } \\
\text { Animal group }\end{array}$ & $\begin{array}{l}\text { BWG } \\
(\mathbf{g})\end{array}$ & $\begin{array}{l}\text { FI } \\
(\mathbf{g})\end{array}$ & FER \\
\hline Control $(-)$ & $0.71 \pm 0.05 \mathrm{a}$ & $10.08 \pm 0.23 \mathrm{~d}$ & $0.070 \pm 0.011 \mathrm{a}$ \\
Control $(+)$ & $0.33 \pm 0.03 \mathrm{~g}$ & $18.58 \pm 0.18 \mathrm{a}$ & $0.018 \pm 0.014 \mathrm{f}$ \\
Fish & $0.63 \pm 0.01 \mathrm{~b}$ & $10.98 \pm 0.24 \mathrm{~d}$ & $0.057 \pm 0.013 \mathrm{~b}$ \\
Meat & $0.62 \pm 0.01 \mathrm{~d}$ & $12.83 \pm 0.29 \mathrm{~b}$ & $0.036 \pm 0.017 \mathrm{~d}$ \\
Chicken & $0.48 \pm 0.02 \mathrm{~d}$ & $10.46 \pm 0.09 \mathrm{~d}$ & $0.046 \pm 0.010 \mathrm{c}$ \\
Egg & $0.44 \pm 0.01 \mathrm{~d}$ & $12.07 \pm 0.09 \mathrm{~b}$ & $0.036 \pm 0.012 \mathrm{~d}$ \\
Soybean & $0.54 \pm 0.62 \mathrm{c}$ & $12.41 \pm 0.23 \mathrm{~b}$ & $0.044 \pm 0.016 \mathrm{c}$ \\
Lentil & $0.36 \pm 0.02 \mathrm{e}$ & $12.48 \pm 1.18 \mathrm{~b}$ & $0.029 \pm 0.015 \mathrm{e}$ \\
White bean & $0.63 \pm 0.03 \mathrm{~b}$ & $11.61 \pm 0.18 \mathrm{c}$ & $0.054 \pm 0.011 \mathrm{~b}$ \\
\hline
\end{tabular}

Values denote arithmetic means \pm standard deviation of the means at $\mathrm{p} \leq 0.05$.
It could be observed from Table (3) that body weight gain for renal failure without dialysis rats $(\mathrm{C}+\mathrm{ve}$ group) was $0.33 \pm 0.03$ compared to $0.71 \pm 0.05 \mathrm{~g} /$ day in $(\mathrm{C}$-ve) normal rats. These results denote that there was significant decrease in BWG of renal failure without dialysis rats as compared to the normal rats. Rats with renal failure without dialysis and fed on all tested protein sources showed significant increase in weight when compared to control positive group. Rats of renal failure without dialysis and fed on fish and white bean showed the highest significant increase in BWG when compared to control positive group, while groups fed on meat, chicken and egg showed the lowest significant decrease in BWG when compared to control positive group.

Concerning food intake (FI), there was a significant increase in control positive group compared to normal rats $(\mathrm{P}<0.05)$, which were $18.58 \pm 0.18$ and $10.0 \pm 0.23$ respectively. All experimental groups showed a significant decrease when compared to positive group. Rats with renal failure without dialysis and fed on fish and chicken showed the highest significant decrease in FI when compared to the positive control group, and at the same time, these groups revealed no significant changes when compared to normal rats.

Regarding the feed efficiency ratio (FER), the positive control group had $0.018 \pm 0.014$, while the negative control 
group had $0.070 \pm 0.011$. The obtained results showed that there was significant decrease in the feed efficiency ratio in the positive control group as compared to the negative control group. In rats with renal failure without dialysis, which was fed on fish and white bean showed the highest significant increase in FER when compared to the positive control group. These results confirm by the findings, which demonstrate that even patients with a mild decline in GFR (i.e., $<50 \mathrm{~mL} / \mathrm{min}$ ) show decreases in their calorie and protein intake as dietary protein intake progressively declines with decreasing GFR [1]. Similarly, a study reported that there is a limited decrease in food intake from 7.26 to $7.15 \mathrm{~g} /$ day (not significant) in normal rats and from 18.61 to $14.72 \mathrm{~g} /$ day (significant) in rats with renal impairment [27].

\subsubsection{Effect of Protein Sources on Kidney Functions (Creatinine, Blood Urea Nitrogen BUN, and Uric Acid) in Renal Failure without Dialysis Rats}

Data presented in table (4) show the effect of fish, meat, chicken, egg, soybean, lentil, and white bean on creatinine, blood urea nitrogen BUN, and uric acid on rats with renal failure without dialysis.

Table (4): Effect of fish, meat, chicken, egg, soybean, lentil, and white bean on creatinine, blood urea nitrogen BUN, and uric acid of renal failure without dialysis rats

\begin{tabular}{llll}
\hline $\begin{array}{l}\text { Parameters } \\
\text { Animal group }\end{array}$ & $\begin{array}{l}\text { Creatinine } \\
(\mathbf{m g} / \mathbf{d L})\end{array}$ & $\begin{array}{l}\text { BUN } \\
(\mathbf{m g} / \mathbf{d L})\end{array}$ & $\begin{array}{l}\text { Uric acid } \\
(\mathbf{m g} / \mathbf{d L})\end{array}$ \\
\hline Control (-) & $0.60 \pm 0.05 \mathrm{~d}$ & $33.00 \pm 2.00 \mathrm{f}$ & $3.50 \pm 0.10 \mathrm{~g}$ \\
Control (+) & $1.30 \pm 0.11 \mathrm{a}$ & $85.80 \pm 2.55 \mathrm{a}$ & $5.20 \pm 0.21 \mathrm{a}$ \\
Fish & $0.83 \pm 0.06 \mathrm{c}$ & $28.00 \pm 0.19 \mathrm{~g}$ & $3.50 \pm 0.13 \mathrm{~g}$ \\
Meat & $0.87 \pm 0.02 \mathrm{c}$ & $39.00 \pm 0.13 \mathrm{e}$ & $4.10 \pm 0.11 \mathrm{f}$ \\
Chicken & $1.00 \pm 0.15 \mathrm{~b}$ & $32.00 \pm 0.25 \mathrm{f}$ & $4.40 \pm 0.23 \mathrm{c}$ \\
Egg & $0.64 \pm 0.04 \mathrm{~d}$ & $38.00 \pm 0.27 \mathrm{e}$ & $4.20 \pm 0.16 \mathrm{e}$ \\
Soybean & $0.80 \pm 0.12 \mathrm{c}$ & $55.00 \pm 1.55 \mathrm{~d}$ & $4.30 \pm 0.20 \mathrm{~d}$ \\
Lentil & $1.00 \pm 0.13 \mathrm{~b}$ & $58.00 \pm 2.11 \mathrm{c}$ & $4.50 \pm 0.25 \mathrm{~b}$ \\
White bean & $0.90 \pm 0.10 \mathrm{c}$ & $66.00 \pm 2.17 \mathrm{~b}$ & $4.40 \pm 0.17 \mathrm{c}$ \\
\hline
\end{tabular}

Among rats with renal failure without dialysis rats, it is apparent that the positive control group had creatinine, urea level and uric acid levels of $1.30 \pm 0.11,85.80 \pm 2.55$ and $5.20 \pm 0.21 \mathrm{mg} / \mathrm{dL}$, while in normal rats had $0.60 \pm 0.05$, $33.00 \pm 2.00$ and $3.50 \pm 0.10 \mathrm{mg} / \mathrm{dL}$ respectively. These findings show that there is a significant increase $(\mathrm{P}<0.05)$ for all of previous mentioned parameters in the positive control group as compared to the negative control group. All rats with renal failure without dialysis and fed on all sources of proteins show significant decrease in creatinine, urea and uric acid. In egg, chicken and fish groups, they exhibit the highest significant decrease $(\mathrm{P}<0.05)$ in creatinine, urea and uric acid respectively, and at the same time these groups reveal non-significant when compared to negative control groups (normal rats).

Another study, which examined the toxicity of urea among dialyzed patients, found out that if BUN levels approach $140 \mathrm{mg} / \mathrm{dL}$ and remain constant for about one week, they cause uremic symptoms [28]. However, moderately high BUN is associated with a few symptoms in individuals with otherwise normal renal function. Therefore, the levels of BUN in the body determine protein intake and reflect the clearance of urea. The relationships between BUN levels and protein intake exist because urea is a product of amino acid catabolism. The major parameter that indicates abnormality in urea metabolism is an increased level of ammonia in arterial blood [29]. Normally, the body can excrete urea via the kidneys, dissolve in the body water, or undergo metabolism into ammonia by gut bacteria. In the body, loss and intake of nitrogen are almost constant; hence, there is not a net loss [30]. A study of individuals with diabetic nephropathy revealed that a soy protein diet has no beneficial impact on proteinuria or renal failure without dialysis [6].

\subsubsection{Effect of Protein Sources on Serum Protein Fractions (Total Protein, Albumin, Globulin, and Albumin/Globulin Ratio) for Renal Failure without Dialysis Rats}

Table (5) shows the effect of fish, meat, chicken, egg, soybean, lentil, and white bean on total protein (T.protein), albumin, globulin, and (albumin globulin (A/G) ratio of rats with renal failure without dialysis.

Table (5): Effect of protein sources on serum protein fractions (Total protein, albumin, globulin, and albumin/globulin ratio) for renal failure without dialysis rats

\begin{tabular}{llll}
\hline $\begin{array}{l}\text { Parameters } \\
\text { Animal group }\end{array}$ & $\begin{array}{l}\text { T. protein } \\
(\mathbf{g} / \mathbf{d L})\end{array}$ & $\begin{array}{l}\text { Albumin } \\
(\mathbf{g} / \mathbf{d L})\end{array}$ & $\begin{array}{l}\text { Globulin } \\
(\mathbf{g} / \mathbf{d L})\end{array}$ \\
\hline Control $(-)$ & $9.30 \pm 0.21 \mathrm{a}$ & $5.60 \pm 0.11 \mathrm{a}$ & $3.70 \pm 0.12 \mathrm{~b}$ \\
Control $(+)$ & $7.80 \pm 0.24 \mathrm{~d}$ & $4.00 \pm 0.22 \mathrm{~g}$ & $3.80 \pm 0.20 \mathrm{a}$ \\
Fish & $7.90 \pm 0.11 \mathrm{~cd}$ & $4.50 \pm 0.23 \mathrm{e}$ & $3.40 \pm 0.23 \mathrm{e}$ \\
Meat & $7.90 \pm 0.12 \mathrm{~cd}$ & $4.20 \pm 0.21 \mathrm{f}$ & $3.70 \pm 0.14 \mathrm{~b}$ \\
Chicken & $8.40 \pm 0.21 \mathrm{~b}$ & $4.80 \pm 0.13 \mathrm{~b}$ & $3.60 \pm 0.10 \mathrm{c}$ \\
Egg & $7.90 \pm 0.23 \mathrm{~cd}$ & $4.70 \pm 0.24 \mathrm{c}$ & $3.20 \pm 0.24 \mathrm{~g}$ \\
Soybean & $7.90 \pm 0.20 \mathrm{~cd}$ & $4.60 \pm 0.14 \mathrm{~d}$ & $3.30 \pm 0.21 \mathrm{f}$ \\
Lentil & $8.00 \pm 0.13 \mathrm{c}$ & $4.50 \pm 0.11 \mathrm{e}$ & $3.50 \pm 0.13 \mathrm{~d}$ \\
White bean & $7.90 \pm 0.14 \mathrm{~cd}$ & $4.20 \pm 0.20 \mathrm{f}$ & $1.33 \pm 0.55 \mathrm{c}$ \\
\hline
\end{tabular}


It is clear from the table that total protein for renal failure without dialysis rats $(\mathrm{C}+\mathrm{ve}$ group) was $7.80 \pm 0.24$ compared to $9.30 \pm 0.21 \mathrm{~g} / \mathrm{dL}$ in $(\mathrm{C}-\mathrm{ve})$ normal rats. These findings indicate that there is a significant decrease in total protein of rats with renal failure without dialysis as compared to normal rats. All rats of renal failure without dialysis and fed on all tested protein sources reveal a significant increase in total protein when compared to control positive group. Chicken group shows the highest significant increase in total protein as compared to the negative control group. Albumin for control positive group is $4.00 \pm 0.22 \mathrm{~g} / \mathrm{dL}$, showing significant decrease when compared to the negative control group, which is $5.60 \pm$ $0.11 \mathrm{~g} / \mathrm{dL}$. All groups show significant increase in serum albumin when compared to control positive group. Additionally, the chicken group shows that it has the highest significant increase in the albumin levels than in all cases of the negative control group.

Globulin for control positive group was $3.80 \pm 0.20 \mathrm{~g} / \mathrm{dL}$, showing a significant increase when compared to $\mathrm{C}-\mathrm{ve}$ the normal rats which was $3.70 \pm 0.12 \mathrm{~g} / \mathrm{dL}$. Among all groups, positive control group shows the highest significant decrease in serum albumin. It is apparent from the table that groups of fish, chicken, egg, soybean and lentil show a significant decrease in globulin not only when compared to the positive control group, but also when compared to the negative control group, thus revealing their role in decreasing globulin in serum as an enhancement for kidney status.

Concerning (albumin globulin $\mathrm{A} / \mathrm{G}$ ) ratio there is a significant decrease in the positive control group when compared to normal rats $(\mathrm{P}<0.05)$, which are $1.05 \pm$ 0.66 and $1.52 \pm 0.52$ respectively. Groups of fish, chicken, egg, soybean, and lentil show a significant increase when compared to the positive control group. Unfortunately, rats with renal failure without dialysis and fed on meat and white bean show no significant changes in $\mathrm{A} / \mathrm{G}$ ratio when compared to the positive control group.

Serum albumin and transferrin levels are widely used to assess nutritional status of an individual [31]. When assessing serum albumin, clinicians should consider that its concentration is determined by many factors, including the synthesis, catabolism, excretion of albumin, changes in plasma volume, and distribution between extracellular and intravascular spaces. In addition, it was reported that albumin could shift into the intravascular compartment. Albumin synthesis and catabolism may also be decreased in malnourished non-uremic subjects, as well as in chronically uremic and nephrotic patients [32]. Consequently, among non-uremic subjects, it is difficult to ascertain total albumin level. Providentially, difference in half-life between transferrin and albumin is a critical indicator of malnutrition because transferrin has a shorter half-life than albumin [33]. However, the transferrin levels vary with hydration and protein turnover; hence, may be affected by inflammation and/or changes in iron stores.

\subsubsection{Effect of Protein Sources on Serum Na and K \\ Levels for Renal Failure without Dialysis Rats}

Data illustrated in table (6) show the effect of fish, meat, chicken, egg, soybean, lentil, and white bean on $\mathrm{Na}$ and $\mathrm{K}$ in renal failure without dialysis rats.

Table( 6): Effect of protein sources on serum $\mathrm{Na}$ and $\mathrm{K}$ levels for renal failure without dialysis rats

\begin{tabular}{lll}
\hline $\begin{array}{l}\text { Parameters } \\
\text { Animal group }\end{array}$ & $\begin{array}{l}\text { Na } \\
(\mathbf{M m o l} / \mathbf{L})\end{array}$ & $\begin{array}{l}\text { K } \\
\mathbf{( M m o l} / \mathbf{L})\end{array}$ \\
\hline Control (-) & $74.00 \pm 1.00 \mathrm{e} \mathrm{f}$ & $10.00 \pm 1.00 \mathrm{a}$ \\
Control (+) & $165.00 \pm 5.00 \mathrm{a}$ & $4.00 \pm 0.50 \mathrm{e}$ \\
Fish & $85.00 \pm 2.00 \mathrm{~d}$ & $8.20 \pm 0.72 \mathrm{~b}$ \\
Meat & $91.30 \pm 3.25 \mathrm{c}$ & $6.08 \pm 1.88 \mathrm{~cd}$ \\
Chicken & $84.80 \pm 1.59 \mathrm{~d}$ & $5.00 \pm 0.55 \mathrm{de}$ \\
Egg & $76.80 \pm 1.58 \mathrm{e}$ & $4.72 \pm 0.63 \mathrm{de}$ \\
Soybean & $72.50 \pm 2.55 \mathrm{f}$ & $4.70 \pm 0.11 \mathrm{de}$ \\
Lentil & $90.00 \pm 5.11 \mathrm{c}$ & $6.50 \pm 0.25 \mathrm{c}$ \\
White bean & $96.00 \pm 2.13 \mathrm{~b}$ & $8.80 \pm 0.19 \mathrm{ab}$ \\
\hline
\end{tabular}

From the data in the table, renal failure without dialysis rats (control positive groups)showed a significant increase $(\mathrm{P}<0.05)$ in $\mathrm{Na}$ while showed a significant decrease $(\mathrm{P}<0.05)$ in $\mathrm{K}$ when compared to control - ve normal rats which were $165.00 \pm 5.00$ and74.00 $\pm 1.00 \mathrm{Mmol} / \mathrm{L}$ for $\mathrm{Na}$ and were $4.00 \pm 0.50$ and $10.00 \pm 1.00 \mathrm{Mmol} / \mathrm{L}$ for $\mathrm{K}$ respectively. All rats of renal failure without dialysis and fed on all tested protein sources revealed significant decrease in serum $\mathrm{Na}$ while showed significant increase when compared to control positive group. Soybean group showed the highest significant decrease in serum $\mathrm{Na}$ as compared to control positive group and showed no significant changes as compared to normal rats. Chicken group showed the highest significant increase in total protein as compared to control -ve group. Early studies revealed that patients with chronic renal failure without dialysis and severe uremia experienced marked symptomatic improvements following dietary protein restricted, prompting its recommendations for dietary therapy [34].

Biochemists have elucidated mechanisms of amino acid metabolism and have found out that the accumulation of inorganic ions and nitrogenous waste products predisposes people to uremia due to clinical and metabolic disturbances. Dietary protein restriction has been used to treat this disorder because excess dietary protein, unlike carbohydrate and fat, is not stored, but is instead degraded to urea and other waste products, which accumulate in patients with impaired renal function. Dietary restriction of protein aids in regulation of potassium, sodium, phosphates, and other ions in the body because proteins contain many ions. Although protein restriction therapy is effective in improving renal failure, insufficient protein intake causes degradation of endogenous protein stores, which help in the 
loss of lean body mass among patients with uremia who are under excessive protein-restricted diets [35]. Differences in amino acid composition explain differential of various proteins on renal function. For instance, the difference between the fish and casein protein is the composition of arginine as fish protein has double proportion of arginine relative to the casein. The mechanism of fish protein is that it inhibits HMG-GA reductase by raising plasma arginine levels and consequently the glucagon level [36]. Moreover, fish protein has more sulfur because cysteine and methionine are sulfur-containing amino acids. Diets rich in cysteine and methionine amino acids are beneficial because they reduce cholesterol levels in rats $[36,37]$.

The other part could be accompanying of complete protein and fish oil. Fish oil is rich in omega 3 fatty acids, several studies indicate that supplementation with fish oil rich in ( $n-3$ PUFA) has beneficial effects on the renal insufficiency. A study demonstrated that the fully defatted fish protein diet does not improve the renal failure compared with the control casein diet in spontaneously hypercholesterolemic rats, whereas a semi-defatted fish protein diet can improve renal function [12]. This suggests that the beneficial effect of the fish protein diet depends on the accompanying fish oil since the fish protein source includes $10 \%$ fat as shown in table1. Clinical and epidemiological studies have shown that fish oil has beneficial effects on the cardiovascular system. Researchers have reported that fish oil prevents hypertension because it lowers blood pressure [38, 39, and 40]. Other researchers have also found similar findings and reported that fish oil is important in the management of cardiovascular disorders $[41,42]$. Therefore, since the findings are relevant to humans, their extrapolation means that consumption fish diet or oil is necessary for patients with chronic renal diseases to manage their conditions. Moreover, since fish diet or oil improves prognosis cardiovascular disorders, it is recommendable that people should use of fish diet in prevention and management of cardiovascular diseases. Thus, further research should continue to study how different protein sources affect renal failure in humans.

\subsection{Histological Results}

As expected, the kidneys from rats in the negative control group had normal histological features of the renal parenchyma (Fig. 1). By contrast, the kidneys from the positive control group showed congestion of the renal blood vessels (Fig. 2). No histopathological changes were observed in the kidneys of rats fed the fish protein diet (Fig. 3). Kidneys from rats fed the meat protein diet exhibited hypertrophic glomerular tufts (Fig.4). Vacuolar degeneration of the endothelial cells in the glomerular tufts was observed in the kidneys from rats fed the chicken protein diet (Fig.5). The kidneys from rats fed the egg protein diet also exhibited vacuolar degeneration of epithelial cells in the renal tubules and the glomerular tufts (Fig. 6). No histopathological changes were observed in the kidneys from rats fed the soybean diet (Fig.7). Finally, the kidneys from rats fed the lentil or white bean protein diets exhibited congestion of the tubular capillaries (Fig.8) and of the renal blood vessels (Fig.9).The present study revealed that no histopathological changes in the kidneys of rats fed the fish or soy protein diets existed; hence, suggesting that these diets did not affect kidney tissues. These results also suggest that the fish protein and soy protein diets may improve the pathological changes in the renal parenchyma of rats with renal failure. These are consistent with the findings, which reported that lowprotein diets protected against histological damage and exhibited improved mortality compared with other diets in rats with experimental chronic renal failure [43].

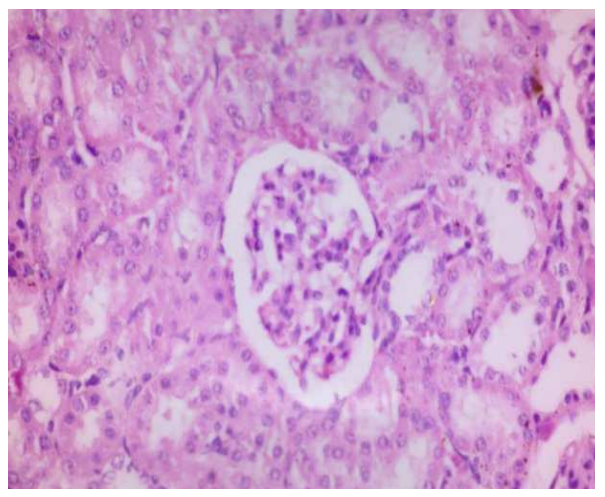

Fig. (1): A kidney from a rat in the negative control group exhibiting normal histological structures of the renal parenchyma (H\&E; original magnification, $200 \times)$.

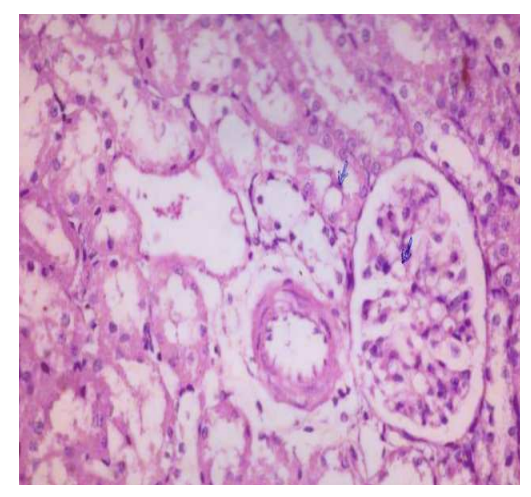

Fig (2): Kidney of rat from group 2 showing vacuolar degeneration of epithelial lining renal tubules and endothelial lining glomerular tufts (H and Ex 200).

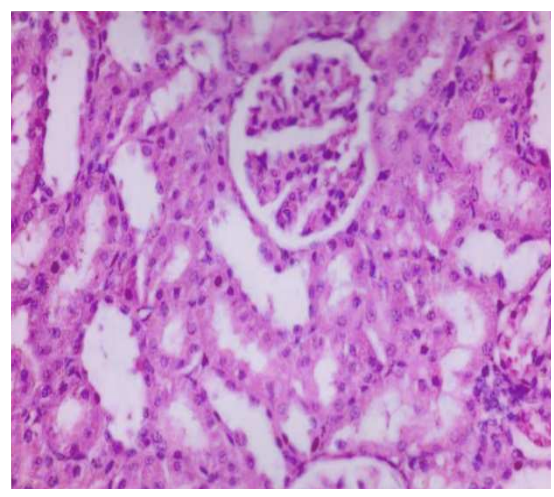

Fig (3): Kidney of rat from group 3 showing no histopathological changes (H and Ex 200). 


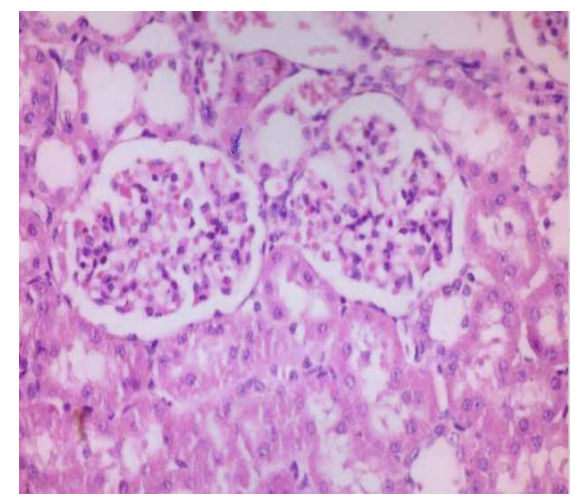

Fig (4): Kidney of rat from group4 showing hypertrophy of glomerular tufts (H and Ex 200).

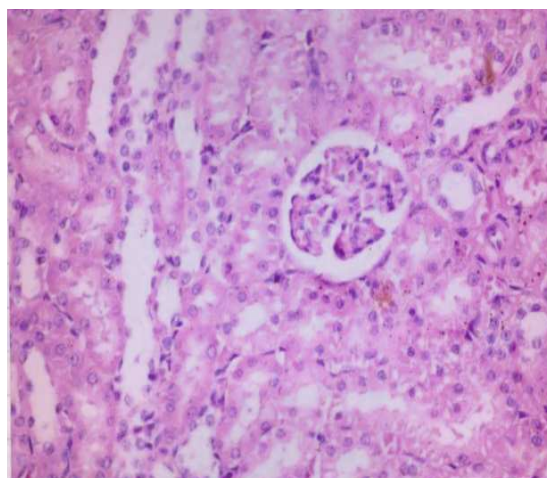

Fig (7): Kidney of rat from group 7 showing no histopathological changes (H and Ex 200).

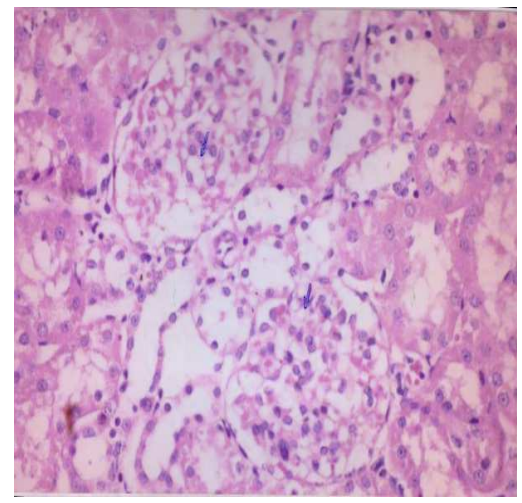

Fig (5): Kidney of rat from group 5 showing vacuolations of endothelia lining glomerular tufts (H and Ex 200).

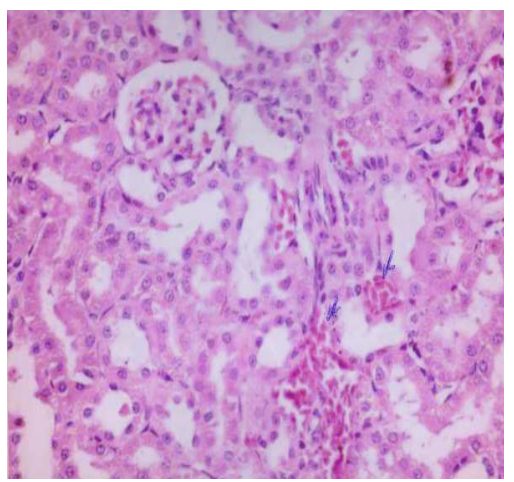

Fig (8): Kidney of rat from group 8 showing congestion of intertubular blood capillaries (H and Ex 200).

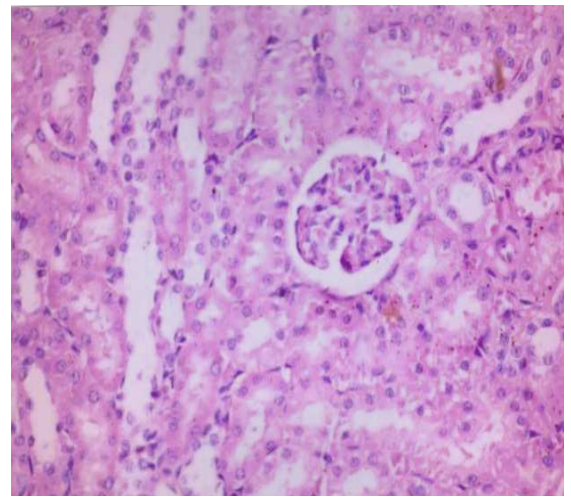

Fig (6): Kidney of rat from group 6 showing vacuolations of epithelial lining renal tubules and endothelial lining glomerular tufts (H and Ex 200).

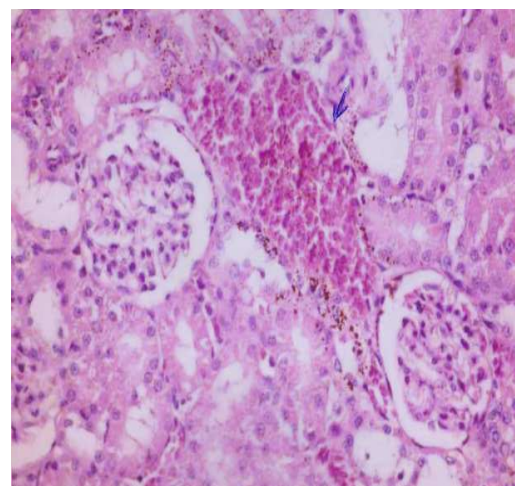

Fig (9): Kidney of rat from group 9 showing congestion of renal blood vessels ( $H$ and $E x$ 200).

\section{Limitation}

In this research I did not find a mechanism explains the role of fish protein in improving renal failure without dialysis, therefore, the study suggested that the effective impact is due to the quality, percentage, and metabolism of amino acids in fish according to the results.

\section{Conclusion}

This study revealed that a low protein diet containing fish protein slowed the progression of chronic failure in rats to a greater degree than the diets containing other protein sources.

\section{Acknowledgments}

The author thanks Prof. Mansour Suliman, the manager of King Fahad Medical Research Center and Dr. Taha Qumusani, Vice Manager of King Fahad Medical Research Center for their support and Dr. Huda Abu-Araki,
Prof.Dr..Fatmaa-AlZhraa Elsharief, Dr. El-Sayed Hamed Assistant Prof. Clinical Nutrition Dept., Faculty of Applied Medical Sciences., Umm Al-Qura University for their help and support during the experimental period.

\section{References}

[1] Mehrotra, R and Kopple, J. D.(2001): Nutritional management of maintenance dialysis patients: why aren't we doing better? Ann Rev Nutr 21: 343-379.

[2] Henderson, J.(2010): Dietary consideration in chronic kidney disease. Natural Medicine Journal 2 (9): 12-15.

[3] Workeneh, B. T and Mitch, W. E.(2010): Review of muscle wasting associated with chronic kidney disease. Am J Clin Nutr 91: 11285-11325.

[4] Barssotti, G.; Morelli. E.; Cupisti, A.; Bertoncini, P. and Giovanetti, S.(1991): A special, supplement "vegan" diet for nephritic patients. Am J Nephrol 11: 380-385.

[5] Barssotti, G., Morelli. E., Cupisti, A., Meda, M., Dani, L. and Giovanetti S. (1996): A low-nitrogen low phosphorous vegan diet for patients with chronic renal failure. Nephron. 
74: 390-394

[6] Anderson, J. W.; Blake, J. E.; Turner, J. and Smith, B. M.(1998): Effects of soy protein on renal function and protein urea in patient: With type 2 diabetes. Am Clin Nutr 68(6): 1347S-1353S

[7] Babji, A. S., Fatimah, S., Ghassem, M. and Abolhassani, Y. (2010) : Protein quality of selected edible animal and plant protein sources using rat bio-assay International Food Research Journal17: 303-308.

[8] Endres,J.G.(2001):Soy protein products: ccharacteristics,nnutritional aaspects, and Utilization, AOAC Press, Champaign, chap. 5, 6. pp. 10-14.

[9] Williams AJ, Walls J.(1987): Metabolic consequences of differing protein diets in experimental renal disease. Eur $\mathrm{J}$ Clin Invest 17:117-122.

[10] Kontessis P, Jones S, Dodds R, Trevisan R,Nosadini R, Fioretto P, Borsato M, SacerdotiD, Di Viberti GC.(1990): Renal metabolic and hormonal responses to ingestion of animal and vegetable proteins. Kidney Int 38:136-144.

[11] Kontessis PS, Bossinakou I, Sarika L, AliopoulouE, Papantonou A, Trevisan R, Roussi D,Stipsanelli K, Grigorakis S, Souvatzog lou A(1995):Renal metabolic and hormonal responses to proteins of different origin in normotensive,nonproteinuric type I diabetic patients. Diabetes Care 18:1233-1240.

[12] Liang, X.M., Otani, H., Z, Q., Tone, Y., Fujii, R., Mune, M., Yukawa, S., Akizawa, T.(2007): Various dietary protein intakes and progression of Renal failure in spontaneously .Nephron Exp. Nephrol 105 : e98-e107.

[13] Soroka N., Silverberga D.S., M. GreemlandcY. BirkdM. BlumaG. PeeraA. Iainaa(1998): Comparison of a VegetableBased(Soya) and an Animal-Based Low-Protein Diet in Predialysis Chronic Renal Failure Patients Nephron 79:173180.

[14] AOAC (2005): Official Methods of Analysis of the Association of Official Analytical Chemists, 18th ed., Washington, DC.

[15] Campbell, J. A. (1963): Methodology of Protein Evaluation. RAG Nutr. Document R.10 Led. 37. June Meeting, New York.

[16] Farombi, O. E. and Ekott, M.(2006): Curccumin atteruates gentamicin induced renal oxidative damage in rats. Food and Chemical Toxicology 44: 1443-1448.

[17] Chapman, D. G.; Castilla, R. and Campbell, J. A. (1959): Evaluation of protein in food I:A method for the determination of protein efficiency ratio. Can. J. of Biochem. Physiol., 37: 679- 686.

[18] Henry, R. J.(1974): Clinical Chemist. Principles and Techniques, 2nd Edition, Hagerstown (MD), Hareer, 1974; Row, PP: 882.

[19] Fossati, P.; Prencipe, L. and Berti, G.(1980): Enzymatic colorimetric method of determination uric acid in serum. Clin Chem 26(2): 227-273.

[20] Patton, C. H. and Crouch, S. R.(1977): Enzymatic colorimetric method to determine urea in serum. Anal Chem 49: 464-469.
[21] Gornall, A. C.; Bardawill, C. J. and David, M. M.(1949): Determination of serum proteins by means of the biuret reaction. J Biol Chem 177: 756.

[22] Doumas, B. T.; Watson, W. A. and Biggs. H. G.(1971): Albumin standard and measurement of serum albumin with bromocresol green. Clin Chem. 31: 87-92.

[23] Carleton, H.(1976): Carlton's Histopathological Technique. 4th Ed., London, Oxford University Paris, New York, Toronto.

[24] Armitage, P. and Berry, G.(1987): Statistical Method in Medical Research. Blackwell, Oxford, UK. PP: 93-213.

[25] Waller, R. A. and Duncan, D. B.(1969): A Bayes rule for the symmetric multiple comparisons problem. Am Sat Assoc. 64 $1484-1503$

[26] Bernstein, A. M.; Trey-Zon, L. and Zhaoping, L.(2007): Are high-protein, vegetable. Based diets safe for kidney function? A review of the literature, Journal of the American Dietetic Association 107: 644-650.

[27] El-Moselhy, S. M.(2006): Influence of some vegetable, spices and herbs on the health status of kidneys as investigated using the experimental animals. M.Sc. Thesis, Faculty of Home Economics, Minufia University.

[28] Johnson, W. J.; Hagge, W. H.; Wagoner, R. D.; Dinapolu, R. P. and RoseEyEar, J. W.(1972): Effects of urea loading in patients with far-advanced renal failure. Mayo Clin Proc 47: 21-29.

[29] Deferrari, G.; Garibotto, G.; Robaudo, C.; Ghiggeri, G. M. and lix-Ianello, R.( 1981): Brain metabolism of amino acids and ammonia in-patients with chronic renal insufficiency. Kidney Int 20: 505-510.

[30] Mitch, W. E.; Lietman, P. S. and Walser, M.(1977): Effects of oral neomycin and kanamycin in chronic renal failure: I. Urea metabolism. Kidney Int 11: 116-122.

[31] Blumenkrantz, M. J.; Kopple, J. D.; Gutman, R. A.; Chan, Y. K.; Barbour, G. L.; Roberts, C.; Shen, F. H.; Gandhi, V. C.; Tucker, C. T.; Curtis, F. K. and Coburn, J. W.(1980): Methods for assessing nutritional status of patients with renal failure. Am J Clin Nutr 33: 1567-1585.

[32] Kaysen, G. A.; Gambertoglio, J.; Jimenez, I.; Jones, H. and Hutchison, F. N.(1986): Effect of dietary protein intake on albumin homeostasis in nephrotic patients. Kidney Int 29: 572-577.

[33] Mitch, W. E. and Walser, M.(1991): Nutritional therapy of the uremic patient, in The Kidney (4th ed), edited by RENNER BM, RECTOR FC, Philadelphia, Saunders, 1991, pp 2186-2222.

[34] Givannetti, S. and Maggiore, Q.(1964): A low-nitrogen diet with proteins of high biological value for severe chronic uremia. Lancet 1: 1000-1003.

[35] Coles, G. A.(1972): Body composition in chronic renal failure. Q. J. Med 41: 25-47.

[36] Sugano, M., Ishiwaki, I. and Nakashima, K., (1984): Dietary protein-dependent modification of serum cholesterol levels in rats : significance of the arginine to lysine ratio. Ann.Nutr.Metab. 28 : 192-199.

[37] Beg, Z.H. and Brewer, H.B. (1982): Modulation of rat liver 
3-hydroxo-3-methylgltaryl coenzyme A reductase activity be reversible phosphorylation. Fed.Proc. $41: 2634-2638$.

[38] Yahia, D.A., Madani, S., Prost, E., Prost, J., Bouchenak, M. and Beileville, J.(2003) : Tissue antioxidant status differ in spontaneously hypertensive rats Fed Fish protein or casein. J.Nutr133: 479-482.

[39] Morris, M.C. (1994): Dietary fats and blood pressure. J.Cardiovasc.Risk. 1:21-30.

[40] Sacks, F.M., Hebert, P., Appel, L.J., Borhani, N.O., Applegate, W.B., Cohen, J.D., Cutier, J.A., Kirchner, K.A., Kuller, L.H. and Roth, K.J. (1994): The effect of fish oil on blood pressure and high-density lipoprotein-cholesterol levels in phase 1 of the trials of hypertension prevention. Trials of Hypertension Prevention Collaborative Research Group. J. Hypertens. 12:S23-S31.
[41] Chen, H.W., Li, C.K., Chen, W.T., Wang, M.L. and Ou, C.C. (1996): Blood pressure-lowering effect of fish oil is independent of thromboxane $\mathrm{A}_{2}$ level in spontaneously hypertensive rats. Prostaglandins Leukot. Essent. Fatty Acids. 54:147-154.

[42] Frenoux, J.M., Prost, E., Belleville, J. and Prost, J. (2001): A polyunsaturated fatty acid diet lowers blood pressure and improves antioxidant status in spontaneously hypertensive rats. J. Nutr. $131: 39-45$

[43] Mitch, W. E.(2000): Dietary therapy in uremia: The impact on nutrition and progressive renal failure without dialysis kidney int., 57, 75: S38 - S43. 